Review

\title{
Current insights into the autotrophic thaumarchaeal ammonia oxidation in acidic soils
}

\author{
Ji-Zheng He ${ }^{\mathrm{a}, *}$, Hang-Wei Hu ${ }^{\mathrm{a}, \mathrm{b}}$, Li-Mei Zhang ${ }^{\mathrm{a}}$ \\ a State Key Laboratory of Urban and Regional Ecology, Research Center for Eco-Environmental Sciences, Chinese Academy of Sciences, Beijing 100085, China \\ ${ }^{\mathrm{b}}$ Graduate School, Chinese Academy of Sciences, Beijing 100049, China
}

\section{A R T I C L E I N F O}

\section{Article history:}

Received 24 December 2011

Received in revised form

3 March 2012

Accepted 5 June 2012

Available online 19 June 2012

\section{Keywords:}

Thaumarchaea

Ammonia oxidation

Acidic soils

Ammonia-oxidizing archaea

Ammonia-oxidizing bacteria

Nitrification

\begin{abstract}
A B S T R A C T
Recent studies of ammonia-oxidizing archaea (AOA) suggested their significant contributions to global nitrogen cycling, and phylogenetic analysis categorized AOA into a novel archaeal phylum, the Thaumarchaeota. AOA are ubiquitous in terrestrial ecosystems, have unique mechanisms for nitrification, better adaptation to low-pH pressures, and strikingly lower ammonia requirements compared with ammonia-oxidizing bacteria (AOB). Previous perceptions that microbial ammonia oxidation in acidic soils was minimal, and entirely meditated by autotrophic bacteria and occasionally by heterotrophic nitrifiers have been dramatically challenged, and the dominant nitrifying groups urgently called for reassessment. Controversially, the relative contributions of AOA and AOB to autotrophic ammonia oxidation have been reported to vary in different soils, but ammonia substrate availability, which was largely restricted under acidic conditions, seemed to be the key driver. Theoretically predicted ammonia concentrations in acidic soils below the substrate threshold of AOB and remarkably high ammonia affinity of AOA raised the supposition that thaumarchaea could represent the dominant ammoniaoxidizing group in ammonia-limited acidic environments. Recently, the functional dominance of thaumarchaea over its bacterial counterpart and autotrophic thaumarchaeal ammonia oxidation in acidic soils has been compellingly confirmed by DNA-stable isotope probing (SIP) experiments and the cultivation of an obligate acidophilic thaumarchaeon, Nitrosotalea devanaterra. Here, we review the currently available knowledge concerning the history and progress in our understanding of the ammoniaoxidizing microorganisms ( $\mathrm{AOB}$ and $\mathrm{AOA}$ ) and the mechanisms of nitrification in nutrient-depleted acidic soils, present the possible mechanisms shaping the distinct niches of $A O A$ and $A O B$, and thus strengthen the assumption that AOA dominate over AOB in ammonia oxidation of acidic soils.
\end{abstract}

(c) 2012 Elsevier Ltd. All rights reserved.

\section{Introduction}

Acidic soils (defined as $\mathrm{pH}<5.5$ in the surface layers) are globally distributed and occupied approximately $30 \%$ of the world's total ice-free lands (Vonuexkull and Mutert, 1995). Besides natural soil acidity and acidification, anthropogenic perturbations in the past several decades, such as huge inputs of artificial nitrogenbased fertilizers in intensive agricultural systems, have greatly accelerated world-scale soil acidification (Vitousek et al., 1997) and global nitrification rates (Le Roux et al., 2003). Nitrification, oxidizing ammonia to nitrate via nitrite, is a crucial process in the global nitrogen cycle. Nitrification and denitrification could significantly contribute to atmospheric emissions of greenhouse

\footnotetext{
* Corresponding author. Tel.: +86 10 62849788; fax: +86 1062923563 .

E-mail address: jzhe@rcees.ac.cn (J.-Z. He).
}

and ozone-depleting gas nitrous oxide $\left(\mathrm{N}_{2} \mathrm{O}\right)$ (Wrage et al., 2001), nitrate leaching to groundwater, and losses of nitrogen-based fertilizers. In addition, nitrification in acidic soil ecosystems could lead to further soil acidification and then increase the exposure risks of plant roots to toxic metals like $\mathrm{Al}^{3+}$ (Carver and Ownby, 1995). Therefore, it is crucial to understand the possible mechanisms of nitrogen transformation in acidic soil ecosystems.

The first observation of nitrification in acidic soils was reported a century ago (Houzeau, 1872). For a long time, this important biogeochemical cycling step of ammonia oxidation was thought to be performed exclusively by bacterial ammonia oxidizers, belonging to two monophyletic groups within $\beta$ - or $\gamma$-proteobacteria (Prosser, 1989; De Boer and Kowalchuk, 2001). However, acidic soils were generally considered detrimental to AOB due to soil acidity pressure, low ammonia substrate availability, presence of natural inhibitive compounds, and increasing toxicity of nitric and nitrous acids (De Boer and Kowalchuk, 2001). Recently, 
metagenomic studies and cultivation-dependent analyses revealed a novel archaeal group capable of oxidizing ammonia, which was completely overlooked in previous studies (Venter et al., 2004; Könneke et al., 2005; Treusch et al., 2005). Physiological characterization of the first AOA isolate, Nitrosopumilus maritimus, and environmental investigations strongly indicated that bulk nitrification in nutrient-depleted open oceans was presumably performed by the abundant thaumarchaea, a deep-branching archaeal phylum (Beman et al., 2008; Brochier-Armanet et al., 2008; Martens-Habbena et al., 2009). Furthermore, genomic studies of $N$. maritimus revealed remarkably divergent pathways of thaumarchaeal ammonia oxidation from bacteria, which potentially offered a significant advantage for thaumarchaea in nutrient-poor environments (Walker et al., 2010). These new findings attracted considerable scientific interest, and raised questions about the relative contributions of thaumarchaea and bacteria to the autotrophic ammonia oxidation in terrestrial environments, particularly in acidic soils.

More and more studies have shown that nitrification can occur in a wide range of acidic soils (Killham, 1990; Degrange et al., 1998; Bottomley et al., 2004; He et al., 2007). It is generally accepted that ammonia $\left(\mathrm{NH}_{3}\right)$ rather than ammonium $\left(\mathrm{NH}_{4}^{+}\right)$could serve as the direct substrate to ammonia monooxygenase (AMO), but ammonia availability is exponentially reduced by decreasing $\mathrm{pH}$ (Suzuki et al., 1974). The theoretically predicted ammonia concentrations in low$\mathrm{pH}$ environments (according to the formula $\mathrm{NH}_{3}+\mathrm{H}^{+} \leftrightarrow \mathrm{NH}_{4}^{+}$;
$\mathrm{pK}_{\mathrm{a}}=9.25$ at $25{ }^{\circ} \mathrm{C}$ ) were significantly below the substrate threshold of cultured AOB, but seemed favorable to AOA which have higher substrate affinity (Stopnišek et al., 2010; Zhang et al., 2012). Competition between AOA and AOB for limited energy sources significantly intensifies under acidic conditions, when ammonia substrate availability becomes extremely limited. Therefore, acidic soil could be considered as an ideal ammonia-limited oligotrophic environment for thaumarchaea, and this hypothesis has been very recently supported by several laboratory microcosm incubations, which indicated a predominant role of thaumarchaeal ammonia oxidation under acidic conditions (Gubry-Rangin et al., 2010; Stopnišek et al., 2010; Zhang et al., 2012). Thus, it is of great importance to understand the possible mechanisms of microbial ammonia oxidation in acidic soils, and reconsider the role of thaumarchaea to meditate nitrification which has been largely underestimated.

\section{Ammonia-oxidizing bacteria and nitrification in acidic soils}

For a long time, nitrification was thought only to be present in neutral and alkaline soils, because many investigations did not detect nitrate in acidic soils, raising the supposition that nitrification could not take place in these low-pH environments (Noyes and Conner, 1919). The first observation of nitrification in acidic soils was reported in 1872 (Houzeau, 1872) (Fig. 1). In 1908, the detection

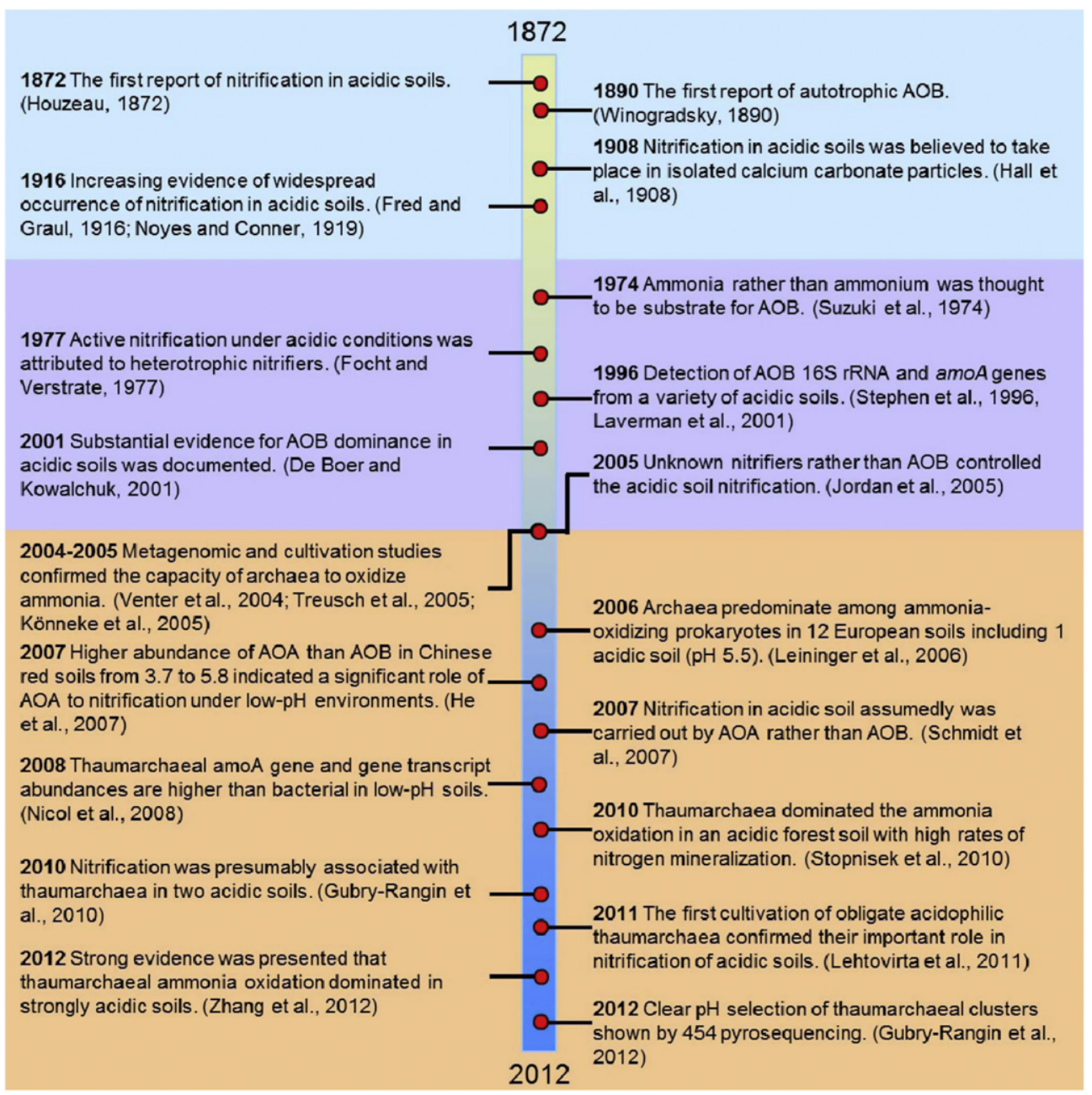

Fig. 1. A general timeline of researches on the nitrification in acidic soils, with emphasis on thaumarchaeal ammonia oxidation. 
of nitrate accumulation in acidic soils was attributed to the probable presence of isolated calcium carbonate particles, which kept restricted neutral and alkaline micro-sites suitable for the nitrification activity (Hall et al., 1908). Since then, pronounced evidence contradicted the previous opinions that nitrification could not exist in acidic soil environments. However, these widely-observed phenomena were entirely attributed to some purely chemical agents, before the discovery of bacterial ammonia oxidizers in actively nitrifying soils (Winogradsky, 1890). Although the responsible microorganisms and relevant mechanisms still remained elusive, the positive correlations between aerobic bacterial numbers and nitrate concentrations began to be noticed (Fred and Graul, 1916; Noyes and Conner, 1919). These early discoveries paved the way for more convincing studies confirming that nitrification was a universal phenomenon in a wide range of acidic soils, and stimulated scientific interests to identify the responsible nitrifiers in soils (De Boer and Kowalchuk, 2001).

AOB were subsequently detected using the Most Probable Number (MPN) method in some natural acidic soils with the numbers in the range of $10^{2}-10^{4} \mathrm{~g}^{-1}$ soil, and were recognized as the responsible nitrifiers in acidic soils, even though the abundance was much lower than that commonly observed in neutral or alkaline agricultural soils $\left(10^{5}-10^{7} \mathrm{~g}^{-1}\right.$ soil) (Hankinson and Schmidt, 1984; De Boer et al., 1988, 1992; Pennington and Ellis, 1993; Carnol and Ineson, 1999; Hastings et al., 2000). PCR-based strategies also detected a wide diversity of AOB-like 16S rRNA and amoA genes from a variety of acidic soils (Stephen et al., 1996; Laverman et al., 2001), but still no studies could directly link AOB existence with in situ acidic soil nitrification.

Several postulated mechanisms to interpret bacterial ammonia oxidation under low-pH conditions have been proposed, including restricted $\mathrm{pH}$-neutral micro-sites (Prosser, 1989), intracellular urea hydrolysis (De Boer and Laanbroek, 1989), acid-tolerant AOB cells (De Boer et al., 1989), high cell density or aggregation, and close associations between $\mathrm{AOB}$ and nitrite-oxidizing bacteria (NOB) (De Boer et al., 1991). However, such mechanisms could not convincingly support the supposition that AOB dominated the autotrophic nitrification under acidic conditions, when considering the usually narrow $\mathrm{pH}$ range for optimal growth of bacteria around neutral or alkaline conditions. The optimal $\mathrm{pH}$ range for bacterial communities is generally constrained between 3 and $4 \mathrm{pH}$ units in pure culture (Rosso et al., 1995). A reduction of $1.5 \mathrm{pH}$ units would significantly impede bacterial activity and net growth, leaving them in an inferior position rapidly outcompeted by other lessinfluenced microorganisms (Rousk et al., 2010). By now, most isolated AOB strains from acidic soils could not be able to oxidize ammonia in liquid batch culture below pH 5.5 (Hankinson and Schmidt, 1984). In some cases, there was evidence for selection of particularly acidophilic AOB strains in low $\mathrm{pH}$ soils, but this was not universal (Nicol et al., 2008).

A number of controversial findings indicated that AOB did not sustain the ammonia oxidation under acidic conditions. Molecular analyses showed that AOB community structure remained relatively stable irrespective of changing nitrification rates (Laverman et al., 2001) and nitrogen mineralization (Mintie et al., 2003 ) in acidic forest soils. Also in grassland soils, community structure of AOB did not shift between different vegetation types, whereas potential nitrification rates changed considerably (Smits et al., 2010). AOB in acidic soils subjected to various levels of nitrogen and sulfur deposition revealed a minor contribution of AOB to autotrophic nitrification (Schmidt et al., 2007). High sensitivity of $\mathrm{AOB}$ to low $\mathrm{pH}$ and inertia to oxidize ammonia in acidic soils were reflected by a significant decrease in abundance with decreasing $\mathrm{pH}$ and a weak correlation between $\mathrm{AOB}$ amoA gene copies and nitrification potential in Chinese acidic red soils
(He et al., 2007; Ying et al., 2010). In some strongly nitrifying acidic soils, AOB was even found to be below the detection limit using the MPN method (Killham, 1990; Papen and Von Berg, 1998). Jordan et al. (2005), who ran an acetylene inhibition experiment, also speculated that some undefined nitrifiers rather than AOB contributed more to the nitrification processes in acidic forest soils receiving high inputs of nitrogen deposition (Jordan et al., 2005). Although heterotrophic nitrifiers, including some bacteria and fungi, could account for a small proportion (usually less than 20\%) of total nitrification in acidic soils (Pedersen et al., 1999; Islam et al., 2007), their minor contribution to nitrification and absence of AOB in a number of actively nitrifying acidic soils led to a growing hypothesis that some unrecognized ammoniaoxidizing microorganisms were more likely to explain the acidic soil nitrification.

\section{Active thaumarchaea in nitrification of acidic soils}

The existence of a novel archaeal group possessing homologs of bacterial ammonia monooxygenase gene was first suggested by metagenomic investigations (Venter et al., 2004; Treusch et al., 2005), and then AOA capacity for oxidizing ammonia was confirmed using the isolated pure strain N. maritimus in 2005 (Könneke et al., 2005) (Fig. 1). This breakthrough discovery opened up a novel perspective to reconsider the mismatch between AOB sensitivity to low $\mathrm{pH}$ and active nitrification in acidic soils. A number of molecular investigations demonstrated that thaumarchaea numerically dominated over their bacterial counterparts in various acidic soils (Leininger et al., 2006; He et al., 2007; Yao et al., 2011), and thaumarchaeal $a m o A$ gene abundance and transcriptional activity were found to increase with decreasing $\mathrm{pH}$ across a soil $\mathrm{pH}$ gradient ranging from 4.9 to 7.5 , with the ratio of $A O A$ versus $A O B$ transcriptional activity reaching the maximum value in the lowest pH soil (Nicol et al., 2008). A similar observation for the trend of the ratios of $\mathrm{AOA}$ versus $\mathrm{AOB}$ amoA gene abundance was observed in Chinese acidic tea orchard soils, where a significant correlation was only found between AOA abundance and potential nitrification rates, with some specific AOA populations welladapted to strongly acidic soils (Yao et al., 2011). Community composition and abundance changes of $\mathrm{AOA}$, rather than $\mathrm{AOB}$, responded sensitively to long-term fertilization in an acidic paddy soil, from which a predominant role of AOA could be inferred (Chen et al., 2011). Moreover, in an acidic forest soil where AOB were below the detection limit, AOA appeared to dominate the active nitrification and preferred to use ammonia produced by mineralization (Stopnišek et al., 2010).

Very recently, ${ }^{13} \mathrm{CO}_{2}$-DNA-SIP experiments convincingly linked the autotrophic nitrification activity in acidic soils with thaumarchaeal ammonia oxidizers (Lehtovirta-Morley et al., 2011; Zhang et al., 2012), and Nitrosotalea devanaterra, a thaumarchaeon enriched from an acidic agricultural soil, was discovered to be chemolithotrophic and obligately acidophilic with optimal growth $\mathrm{pH}$ in the range 4-5 (Lehtovirta-Morley et al., 2011). In addition, $\mathrm{pH}$ selection of soil thaumarchaeal ammonia oxidizers at local, regional and global scales was demonstrated by 454 barcoded pyrosequencing, which identified some well-supported phylogenetic lineages with specific adaptation to acidic, acido-neutral and alkalinophilic soils (Gubry-Rangin et al., 2011). These studies provide a powerful explanation for high rates of nitrification in acidic soils and conclusively confirm the vital role played by thaumarchaea to meditate ammonia oxidation in acidic soils.

The isolated and enriched cultures of Group I.1a N. maritimus, Cenarchaeum symbiosum, Nitrosoarchaeum limnia, and Nitrosoarchaeum koreensis, Group I.1a-associated N. devanaterra, Group I.1b Nitrososphaera viennensis and Nitrososphaera gargensis, ThAOA/ 
HWCG III Nitrosocaldus yellowstonii have shown a capacity to oxidize ammonia (Könneke et al., 2005; Hallam et al., 2006; de la Torre et al., 2008; Hatzenpichler et al., 2008; Blainey et al., 2011; Jung et al., 2011; Lehtovirta-Morley et al., 2011; Tourna et al., 2011). Group I.1a-associated and I.1b thaumarchaea were shown to participate in the ammonia oxidation processes of strongly acidic soils using the ${ }^{13} \mathrm{CO}_{2}$-SIP approach in soil microcosms (Zhang et al., 2012). In addition, an unrecognized amoA-cluster has been identified from the amoA-gene-based phylogenetic trees, which has not been definitely linked with 16S rRNA-based thaumarchaeal lineage, but was speculated to include the Group I.1c archaea (Pester et al., 2011).

Group I.1c archaea was first described in a boreal forest soil (Jurgens et al., 1997), and was then found to predominate the archaeal 16S rRNA genotypes in two temperate acidic forest soils (Kemnitz et al., 2007). Furthermore, an apparent preference for lower $\mathrm{pH}$ could be inferred from a series of molecular surveys with the greatest gene abundance occurring in the lowest $\mathrm{pH}$ soil and even below detection limit at near-neutral pH (Nicol et al., 2005; Kemnitz et al., 2007). In the long-term pH-manipulated Craibstone soils, Group I.1c was only detected by cloning library in $\mathrm{pH} 4.9$ soil plots (Nicol et al., 2008). Lehtovirta-Morley et al. (2009) found that soil $\mathrm{pH}$ was the key driver regulating the abundance and community structure of Group I.1c in a wide range of soil habitats, and this distinct lineage dominated the archaeal communities in most of acidic soils (Table 1). Community structures of soilinhabiting Group I.1c was influenced by Scots pine ectomycorrhizae, leading to a supposition that it was heterotrophic (Bomberg and Timonen, 2007). However, despite of the widespread distribution of Group I.1c archaea in acidic soils, little is known of its particular ecological function, and its abundance was still not directly associated with the ammonia-oxidizing activity. Furthermore, as yet no cultured thaumarchaea belonged to Group I.1c. In a recent DNA-SIP microcosm incubated with acidic soils, Group I.1c archaea was retrieved in both light and heavy fractions during 30 days' active nitrification, however, no quantitative PCR was performed to detect the labeling of ${ }^{13} \mathrm{CO}_{2}$, thus its potential involvement in ammonia-oxidizing function of acidic soils still remained unclear (Zhang et al., 2012).

\section{Possible mechanisms of thaumarchaeal ammonia oxidation in acidic soils}

\subsection{Ammonia-limited acidic soils and high affinity for ammonia by thaumarchaea}

The ammonia oxidation step provides the sole energy source for the slow-growing nitrifying microorganisms, so ammonia substrate availability was thought to be a dominant factor dictating the differential growth and ecological niches of $\mathrm{AOA}$ and $\mathrm{AOB}$ (Martens-Habbena et al., 2009; Schleper, 2010; Verhamme et al., 2011). Previous studies suggested that the presence of some unknown nitrifiers might be responsible for the ammonia oxidation in some low ammonia-containing ecosystems, because the in situ substrate concentrations were significantly below the growth requirement of AOB cultures (Prosser, 1989). Similarly, in a survey of non-fertilized, mineral-fertilized and organic + mineral-fertilized soils, the highest ratios of $\mathrm{AOA}$ to $\mathrm{AOB}$ amoA gene copies were found in the nutrient-limited non-fertilized soils (Leininger et al., 2006). In a series of soil microcosms with low background ammonia concentrations and incubated with no external nitrogen amendments, AOA was found to primarily control the nitrification (Offre et al., 2009; Gubry-Rangin et al., 2010; Zhang et al., 2010, 2012). In contrast, in some soils regularly supplied with nitrogen fertilizers, $A O B$ was thought to be mainly responsible for the ammonia oxidation (Jia and Conrad, 2009; Xia et al., 2011), and AOB growth was also observed to benefit from increased ammonium availability (Schauss et al., 2009; Verhamme et al., 2011). AOB abundance responded positively to the amendment of nitrogen fertilizer and correlated well with nitrification activity in heavily fertilized soils (Di et al., 2009, 2010) or wetland (Levicnik-Höfferle et al., 2010), whereas AOA growth was suppressed by high levels of ammonium in soil microcosms (Verhamme et al., 2011).

The questions about their relative contributions should be much clearer if the actual ammonia concentrations could be taken into account. Generally assuming the soil water content of $25 \%$ and the ionization equilibrium constant $\mathrm{pK}_{\mathrm{a}} 9.25$ at $25{ }^{\circ} \mathrm{C}$, ammonia concentrations in several soil microcosms could be theoretically predicted from the total ammonium concentrations (Table 2 ). It is

Table 1

Studies reporting Group I.1c thaumarchaea in soil ecosystems.

\begin{tabular}{|c|c|c|c|}
\hline Soil sample & $\mathrm{pH}$ range & Findings & References \\
\hline Scottish pH-manipulated plots & $4.5-7.5$ & $\begin{array}{l}\text { Group I.1c was only detected in } \mathrm{pH} 4.5-6.0 \text {, and increased } \\
\text { steadily as } \mathrm{pH} \text { decreased, with the highest abundance } \\
\text { occurring in the lowest } \mathrm{pH} \text { soil. }\end{array}$ & Lehtovirta-Morley et al., 2009 \\
\hline Various types of soils & $3.9-6.6$ & $\begin{array}{l}\text { High abundance of Group I.1c was observed in acidic soils } \\
\text { with distinct characteristics at } \mathrm{pH} 3.9-5.7 \text {, accounting for } \\
36 \%-69 \% \text { of total Crenarchaeota. }\end{array}$ & Lehtovirta-Morley et al., 2009 \\
\hline A temperate acidic forest soil & $3.8-4.3$ & $\begin{array}{l}\text { T-RFLP and clone libraries analysis demonstrated that Group I. } \\
\text { 1c constituted a significant proportion of the archaeal phenotypes } \\
\text { in the tested acidic forest soil, implying a crucial functional role. }\end{array}$ & Kemnitz et al., 2007 \\
\hline A glacier foreland soil & $4.2-7.5$ & $\begin{array}{l}\text { Group I.1c was the primary component of archaeal community } \\
\text { only in more developed soil with a pH value of } 4.2 \text {, and its } \\
\text { diversity was not influenced by plant species rhizosphere. }\end{array}$ & Nicol et al., 2005 \\
\hline An organic acidic forest soil & 4.1 & $\begin{array}{l}29 \% \text { of archaeal } 16 \text { S rRNA genes were placed into Group I.1c } \\
\text { but without evidence for their involvement in nitrification. }\end{array}$ & Stopnišek et al., 2010 \\
\hline Various soil ecosystems & $5.0-9.5$ & $\begin{array}{l}\text { The relative abundance of Group I.1c in Marburg acidic forest } \\
\text { soil was much higher than that in sandy meadow soil. }\end{array}$ & Ochsenreiter et al., 2003 \\
\hline Chinese acidic red soils & $4.0-4.3$ & $\begin{array}{l}\text { Group I.1c and I.1c-associated sequences prevailed in the } \\
\text { degradation plot }(\mathrm{pH}=4.33) \text {, but no amplified archaeal } \\
\text { amoA genes could be linked with Group I.1c. }\end{array}$ & Ying et al., 2010 \\
\hline Chinese strongly acidic soils & $4.2-4.5$ & $\begin{array}{l}{ }^{13} \mathrm{CO}_{2} \text {-DNA-SIP revealed that Group I.1c archaea might } \\
\text { be labeled during } 30 \text { days' active nitrification, indicating an } \\
\text { autotrophic growth lifestyle. Although no direct evidence } \\
\text { confirmed the presence of } a m o A \text { genes in Group I.1c, its } \\
\text { potential involvement in ammonia oxidation could not be overlooked. }\end{array}$ & Zhang et al., 2012 \\
\hline
\end{tabular}


Table 2

Ammonia oxidizers and nitrification activity in various soil microcosms.

\begin{tabular}{|c|c|c|c|c|c|}
\hline \multirow[t]{2}{*}{ Soil type } & \multirow[t]{2}{*}{ Soil pH } & \multicolumn{2}{|l|}{ Ammonia concentration } & \multirow{2}{*}{$\begin{array}{l}\text { The dominant } \\
\text { nitrifier }\end{array}$} & \multirow[t]{2}{*}{ References } \\
\hline & & The initial $\mathrm{NH}_{4}^{+}$concentration $\left(\mathrm{mg} \mathrm{kg}^{-1}\right)$ & Theoretic $\mathrm{NH}_{3}$ concentration ${ }^{\mathrm{a}}$ & & \\
\hline Agricultural, pH-regulated plots & 7.0 & 0.6 & $0.964 \mu \mathrm{M}$ & Thaumarchaea & Offre et al., 2009 \\
\hline Agricultural, pH-regulated plots & 7.5 & 3.2 & $1.22 \mu \mathrm{M}$ & Thaumarchaea & Zhang et al., 2010 \\
\hline Agricultural, pH-regulated plots & 4.5 & 0.86 & $0.00437 \mu \mathrm{M}$ & Thaumarchaea & Gubry-Rangin et al., 2010 \\
\hline Agricultural, pH-regulated plots & 6.0 & 0.59 & $0.0948 \mu \mathrm{M}$ & Thaumarchaea & Gubry-Rangin et al., 2010 \\
\hline Agricultural, tea orchard & 4.2 & 39.2 & $0.0246 \mu \mathrm{M}$ & Thaumarchaea & Zhang et al., 2012 \\
\hline $\begin{array}{l}\text { Agricultural, rotated maize, } \\
\text { wheat and barley }\end{array}$ & 7.0 & 4.19 & $6.73 \mu \mathrm{M}$ & Bacteria & Jia and Conrad, 2009 \\
\hline Agricultural, sandy & 8.0 & 1.13 & $323 \mu \mathrm{M}$ & Bacteria & Xia et al., 2011 \\
\hline
\end{tabular}

${ }^{\text {a }} \mathrm{NH}_{3}$ concentrations in this table are theoretically predicted based on the equilibrium $\left(\mathrm{NH}_{3}+\mathrm{H}^{+} \leftrightarrow \mathrm{NH}_{4}^{+} ; \mathrm{pK}_{\mathrm{a}}=9.25\right)$ at $25{ }^{\circ} \mathrm{C}$.

clear that the low-level ammonia concentrations ranging from $0.00437 \mu \mathrm{M}$ to $1.22 \mu \mathrm{M}$ selectively favored the growth of AOA. However, when the initial ammonia concentrations were higher $(6.73-323 \mu \mathrm{M})$ and weekly satisfied by high-level amendments ranging from $643 \mu \mathrm{M}$ to $6428 \mu \mathrm{M}$ (four times of weekly $100 \mathrm{mg}$ $\mathrm{NH}_{4}^{+} \mathrm{kg}^{-1}$ soil inputs), AOB was observed to primarily control the nitrification activity (Table 2 ).

In addition to environmental investigations and laboratory microcosms, more evidence supporting the thaumarchaeal preference for low ammonia comes from ecophysiological features of the cultivated AOA strains, involving the lower inhibitory ammonia concentrations and higher affinity for ammonia. Observed inhibitory ammonia concentrations $(0.89-356 \mu \mathrm{M})$ in all the currently available cultures or enrichments of thaumarchaea from marine and terrestrial ecosystems are considerably lower than the substrate threshold of cultured AOB (394-40,000 $\mu \mathrm{M}$ ) (Table 3), indicating a narrow and lower substrate span for AOA. The bulk nitrification in nutrient-depleted open ocean has been presumed to be linked with the abundant AOA, where the typical ammonium concentrations ranged between 0.03 and $1 \mu \mathrm{M}$ (Beman et al., 2008; Erguder et al., 2009). This range is very similar to the apparent $K_{\mathrm{m}^{-}}$ value $(0.13 \mu \mathrm{M}$ ammonium) of the marine-isolated $N$. maritimus which is by now the lowest half-saturation constant among all the cultured ammonia oxidizers (Martens-Habbena et al., 2009). Further, two enriched AOA strains also have a lower $K_{\mathrm{m}}$-value from 0.61 to $0.69 \mu \mathrm{M}$ ammonium (Park et al., 2010; Jung et al., 2011). In comparison, the half-saturation constant $K_{\mathrm{m}}$ of cultured AOB ranged from $50 \mu \mathrm{M}$ to $1780 \mu \mathrm{M}$ ammonium (Table 3). Therefore, AOA showed a much higher affinity for ammonia, more than 200fold higher than that of reported AOB strains (Martens-Habbena et al., 2009), accounting for the specific ability of AOA to use lowlevel ammonia and compete efficiently for the limited substrate with $\mathrm{AOB}$. Therefore, the higher capacity to use ammonia substrate, and low-pH-reduced ammonia availability in acidic soils, provide major advantages for $\mathrm{AOA}$ dominance over $\mathrm{AOB}$ in these environments.

\subsection{Nitrogen sources for thaumarchaea in acidic soils}

Despite increasing evidence supporting the thaumarchaeal preference for ammonia-poor environments, of particular interest is which kind of ammonia can serve as the nitrogen source for thaumarchaea, since different types of (inorganic or organic) fertilizer have contrasting influences on the corresponding ammonia-oxidizing groups (Hai et al., 2009). A broad survey of soils demonstrated a positive relationship between mineralization rates

Table 3

Parameters for several enriched or pure cultures of thaumarchaeal or bacterial ammonia oxidizers.

\begin{tabular}{|c|c|c|c|c|c|c|c|}
\hline \multirow[t]{2}{*}{ Cultured nitrifiers } & \multirow[t]{2}{*}{ Descriptions } & \multirow[t]{2}{*}{$\mathrm{pH}$} & \multicolumn{2}{|c|}{ Observed inhibitory concentrations } & \multicolumn{2}{|c|}{ Half-saturation constant $\left(K_{\mathrm{m}}\right)$} & \multirow[t]{2}{*}{ References } \\
\hline & & & $\mathrm{NH}_{4}^{+}(\mu \mathrm{M})$ & $\mathrm{NH}_{3}(\mu \mathrm{M})^{\mathrm{a}}$ & $\mathrm{NH}_{4}^{+}(\mu \mathrm{M})$ & $\mathrm{NH}_{3}(\mu \mathrm{M})^{\mathrm{a}}$ & \\
\hline Nitrosopumilus maritimus & AOA from marine aquarium & 7.5 & 2000 & 35.6 & 0.13 & 0.0023 & Martens-Habbena et al., 2009 \\
\hline Nitrososphaera gargensis & Enriched thermophilic AOA & 7.8 & 3080 & 109 & $N A^{b}$ & NA & Hatzenpichler et al., 2008 \\
\hline Nitrosocaldus yellowstonii & Enriched thermophilic AOA & 7.5 & NA & NA & NA & NA & de la Torre et al., 2008 \\
\hline Nitrososphaera viennensis & Soil isolated $\mathrm{AOA}$ & 7.5 & 20,000 & 356 & NA & NA & Tourna et al., 2011 \\
\hline Nitrosotalea devanaterra & Obligate acidophilic AOA & 4.5 & 50,000 & 0.89 & NA & NA & Lehtovirta-Morley et al., 2011 \\
\hline Nitrosoarchaeum koreensis & Soil enriched AOA & 7.0 & 20,000 & 112 & 0.69 & 0.04 & Jung et al., 2011 \\
\hline AR enrichment culture & Marine sediment AOA & 7.0 & 40,000 & 224 & 0.61 & 0.02 & Park et al., 2010 \\
\hline $\begin{array}{l}\text { Nitrosomonas europaea } \\
\quad \text { ATCC } 19718\end{array}$ & $\begin{array}{l}\text { Obligate lithoautotrophic } \\
\text { AOB }\end{array}$ & 8.2 & 263,000 & 40,000 & NA & NA & Sato et al., 1985 \\
\hline $\begin{array}{l}\text { Nitrosomonas Cluster } \\
\quad \text { 6a G5-7 }\end{array}$ & $\begin{array}{l}\text { AOB from freshwater } \\
\text { sediment }\end{array}$ & 7.8 & NA & NA & $50-100$ & $1.77-3.55$ & Bollmann et al., 2002 \\
\hline Nitrosomonas oligotropha & AOB from river estuary & 7.8 & 50,000 & 1774 & $50-116$ & $1.77-4.12$ & Stehr et al., 1995 \\
\hline $\begin{array}{l}\text { Nitrosospira strains } 40 \mathrm{~K} 1 \text {, } \\
\quad \text { AF, B6, L115 }\end{array}$ & Soil-isolated AOB & 7.8 & NA & NA & $208-380$ & $7.38-13.5$ & Jiang and Bakken, 1999 \\
\hline Nitrosomonas sp. GH22 & AOB in activated sludges & 7.4 & NA & NA & 1780 & 25 & Suwa et al., 1994 \\
\hline $\begin{array}{l}\text { Nitrosomonas europaea } \\
\quad \text { Nm35 }\end{array}$ & Soil-isolated AOB & 8.0 & 7000 & 394 & 460 & 25.9 & Groeneweg et al., 1994 \\
\hline $\begin{array}{l}\text { Nitrosospira briensis } \\
\quad \text { ATCC } 25971\end{array}$ & Soil-isolated AOB & 7.5 & NA & NA & 167 & 3.0 & Bollmann et al., 2005 \\
\hline $\begin{array}{l}\text { Nitrosomonas europaea, } \\
\text { N. eutropha, } N \text {. halophila } \\
\text { and } N \text {. mobilis }\end{array}$ & $\begin{array}{l}\text { AOB from sewage, } \\
\text { freshwater and brackish } \\
\text { water }\end{array}$ & NA & NA & NA & $420-750$ & $30-61$ & $\begin{array}{l}\text { Koops and Pommerening-Roser, } \\
2001\end{array}$ \\
\hline Nitrosomomas cryotolerans & Obligately halophilic AOB & NA & NA & NA & NA & $42-59$ & $\begin{array}{l}\text { Koops and Pommerening-Roser, } \\
2001\end{array}$ \\
\hline
\end{tabular}

\footnotetext{
${ }^{\text {a }} \mathrm{NH}_{3}$ concentrations in this table are theoretically predicted based on the equilibrium $\left(\mathrm{NH}_{3}+\mathrm{H}^{+} \leftrightarrow \mathrm{NH}_{4}^{+} ; \mathrm{pK}_{\mathrm{a}}=9.25\right)$ at $25^{\circ} \mathrm{C}$.

b NA, not available.
} 
and net nitrification rates, indicating an important role of mineralized ammonia substrate for the following nitrification processes (Booth et al., 2005). There is also evidence that potential nitrification rates were only enhanced by manure treatment but suppressed by mineral fertilizers (Fan et al., 2011) in some soils. Actually, nitrification correlated with nitrogen mineralization rather than ammonium availability in acidic soils has also been indicated in several previous environmental investigations (Kreitinger et al., 1985; Strong et al., 1997; Frank et al., 2000) and gross nitrogen mineralization in acidic forest soils has been recognized as a good index of ammonia availability for autotrophic ammonia oxidizers (Hart et al., 1997). Similar observations were also made in Chinese acidic red soils where potential nitrification rates were substantially reduced by long-term additions of mineral fertilizers but increased by manure addition (He et al., 2007).

Further evidence came from a number of microcosm experiments aiming to identify the dominant ammonia-oxidizing agents. Thaumarchaeal growth was significantly increased by root exudation in a paddy rhizosphere soil, but less affected by addition of inorganic fertilizers (Chen et al., 2008). In a low-ammonia acidic forest soil, continuous ammonia flush from mineralization of organic nitrogen, but not added inorganic nitrogen, was thought to be the major substrate source for thaumarchaeal nitrification processes (Stopnišek et al., 2010). This hypothesis was verified by measuring the effects of inorganic and organic nitrogen resources on acidic soil nitrification, where thaumarchaeal abundance was unaffected by inorganic ammonium, but significantly stimulated by organic nitrogen addition (Levicnik-Höfferle et al., 2012). Similar observations that ammonia resources generated from mineralization of organic matter stimulated nitrification were also recorded in soil incubations without external nitrogen addition (Offre et al., 2009; Gubry-Rangin et al., 2010; Zhang et al., 2010). Active nitrification dominated by thaumarchaea in a strongly acidic soil, showed by our recent DNA-SIP work, was also positively associated with the high rates of nitrogen mineralization (Zhang et al., 2012). On the contrary, high rates of inorganic ammonium supply did not stimulate thaumarchaeal ammonia oxidation in a number of neutral and alkaline soils (Jia and Conrad, 2009; Levicnik-Höfferle et al., 2010; Verhamme et al., 2011) as well as in acidic soils (Stopnišek et al., 2010).
In fact, ammonia produced from organic matters is not functionally different from ammonia localized in soil water $\left(\mathrm{NH}_{3}+\mathrm{H}^{+} \leftrightarrow \mathrm{NH}_{4}^{+}\right)$, even though numerous evidence revealed that thaumarchaea preferred to utilize mineralized ammonia resources. A possible explanation is that continuous flux of low-level ammonia substrate via mineralization under acidic environments is sufficient to satisfy the low-ammonia requirement of thaumarchaea, but provides a selective pressure for both thaumarchaea and bacteria. Better adaptation of archaea to chronic energy stress than bacteria (Valentine, 2007), and their specific preference for low ammonia ensure that thaumarchaea outcompete bacteria under such a chronic energy stress. Another possible explanation is that ammonia released by mineralization is more available to thaumarchaea cells than inorganic ammonia from $\mathrm{NH}_{3} / \mathrm{NH}_{4}^{+}$equilibrium in soil water. Because mineralizer may directly transport ammonia to thaumarchaea to enable rapid oxidation of ammonia, thus aggregates of ammonia oxidizers and mineralizers might form in acidic soils (Levicnik-Höfferle et al., 2012). However, the diversity and abundance of nitrogen-mineralizing microorganisms are rarely known, nor is their possible aggregate formation with ammonia oxidizers.

Another proposed mechanism was a mixotrophic lifestyle of thaumarchaea, which is assimilation of organic matters, followed by the intracellular mineralization and ammonia oxidation in thaumarchaea cells (Levicnik-Höfferle et al., 2012) (Fig. 2). Genomic analyses of $C$. symbiosum and $N$. maritimus identified the presence of genes required for the oxidative TCA cycle and potential organic substrate transporters, indicating the thaumarchaeal potential to use other reduced nitrogen as an energy source and a mixotrophic or heterotrophic lifestyle (Hallam et al., 2006; Walker et al., 2010). Actually, thaumarchaea can use some alternative substrates than ammonia for an energy source, as revealed by the recently soilisolated archaeon, $N$. viennensis, which could grow mixotrophically on urea or ammonia with addition of pyruvate (Tourna et al., 2011), and as indicated by assimilation of organic matters through marine thaumarchaeal lipids (Ingalls et al., 2006). Also in a microcosm study, when autotrophic ammonia oxidation was completely inhibited by acetylene, thaumarchaeal growth was still observed, strongly suggesting a mixotrophic or heterotrophic catabolism (Jia and Conrad, 2009). Therefore, a broader substrate spectrum does

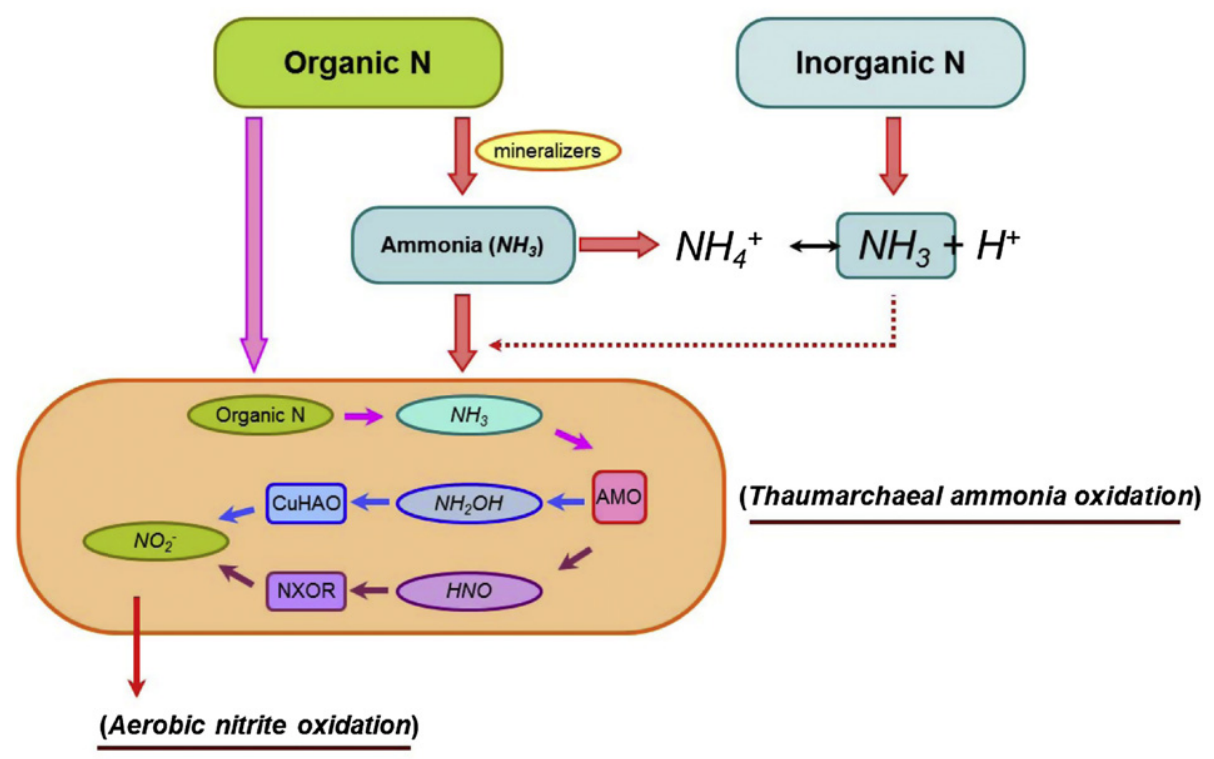

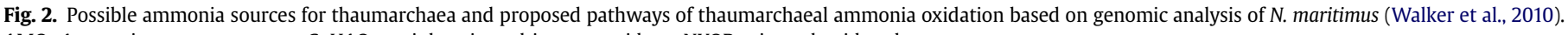
AMO: Ammonia monooxygenase; CuHAO: periplasmic multicopper oxidase; NXOR: nitroxyl oxidoreductase. 
exist for thaumarchaea and their actual nitrogen resources under acidic conditions remain to be fully investigated. At the same time, these mixotrophic thaumarchaeal characteristics are also encountered in $\mathrm{AOB}$, because previous investigations have revealed that Nitrosomonas europaea could use fructose (Hommes et al., 2003) and amino acids (Frijlink et al., 1992) as their carbon sources. Thus, AOA dominance over AOB under this mechanism in acidic soils still needs careful consideration.

\subsection{Unique biochemical and genetic features of thaumarchaea}

Ecological niche separation between thaumarchaea and bacteria basically originates from their different biochemical and genetic features. Although numerous findings have demonstrated the broad distributions of archaea in diverse moderate environments, they are still mainly considered as extremophiles, well-adapted to thrive in some unfavorable habitats, such as high-temperature, salt-saturated and strongly acidic environments (Schleper et al., 2005). Thaumarchaeal amoA gene copy numbers, but not bacterial, remained almost stable along a changing salinity gradient, indicating a high tolerance of AOA to salinity pressures (Santoro et al., 2008). Moreover, a sedimentary AOA strain was selectively enriched over AOB from reduced oxygen levels caused by coculture with sulfur-oxidizing bacteria (SOB), suggesting a favorable niche of AOA in oxygen-limited environments (Park et al., 2010). Valentine (2007) proposed that the key biochemical basis for archaeal adaptation to chronic energy stress could be primarily attributed to their specific tetraether-based membrane composition. Compared with bacterial membranes, archaeal membranes are commonly less permeable to ions thereby reducing the futile ion cycling and enabling an energetic advantage for archaea (Valentine, 2007). Such low-permeability membrane may help thaumarchaeal cells keep intracellular $\mathrm{pH}$ close to neutral, enabling an undisturbed ammonia oxidization process. Simultaneously, Valentine (2007) contended that in order to outcompete bacteria, archaea have evolved to possess some unique catabolic pathways, like ammonia oxidation activity of thaumarchaea, whose ability under specific conditions (e.g. low-pH environment) is much stronger than their bacterial counterpart.

Presently, complete genome sequences of only three cultured thaumarchaeons, $N$. maritimus, $C$. symbiosum and $N$. limnia, are available for further analysis of their unique features (Hallam et al., 2006; Walker et al., 2010; Blainey et al., 2011). Genome features of these AOA strains suggested a distinctly divergent pathway for ammonia oxidation from known $A O B$, because they lacked the genes encoding a homolog of AOB-like hydroxylamine oxidoreductase (HAO) and cytochrome $c$ proteins, and structural differences between archaeal and bacterial amo genes. Thus, it remains to be known whether AOA may use hydroxylamine as an intermediate, or contain some novel enzymes for the oxidation of hydroxylamine. In fact, a hypothetical model has been proposed simultaneously without using hydroxylamine as intermediate. This model proposes that two oxygen atoms are inserted into ammonia to form $\mathrm{HNOHOH}$ and then decayed to the intermediate nitroxyl (HNO) by archaeal AMO, in this way eliminating the reductant recycling in the initial oxygenase reaction, and indicating an ecological advantage of AOA over AOB in nutrient-limited environments (Walker et al., 2010) (Fig. 2). Further ecological advantages of AOA in acidic soils could be inferred from their highly copper-dependent systems to oxidize ammonia and transport electrons (Hallam et al., 2006; Walker et al., 2010; Blainey et al., 2011), because of the increasing copper availability in acidic soils (Goedert et al., 1997). Thirdly, the 3-hydroxypropionate/4hydroxybutyrate pathway for carbon fixation by AOA is more energy-efficient than the bacterial Calvin-Bassham-Benson cycle
(Walker et al., 2010). Moreover, as in the AOB genomes, the existence of ammonium transporter genes was also identified in all three AOA genomes (Hallam et al., 2006; Walker et al., 2010; Blainey et al., 2011). It has been proposed that such active transport of ammonium might facilitate the regulation of AMO and improve the ammonia uptake into AOB cells (Arp et al., 2002). If the active assimilation of ammonium was a necessary function for AOA, it would enable AOA effectively competing with AOB under ammonia-limited acidic conditions, apart from the passive diffusion of ammonia into the cells. Taken together, these advantageous intrinsic features possessed by AOA put them in a superior position when competing with AOB in acidic soils.

The above proposed mechanisms still need careful verification tests to check their suitability to drive the thaumarchaeal dominance in various acidic soil environments. On the other hand, some other mechanisms used to explain the bacterial ammonia oxidation in acidic environments can also be employed to interpret the thaumarchaeal nitrification, such as increased ureolytic activity (Burton and Prosser, 2001), aggregated ammonia oxidizers (De Boer et al., 1991), pH-neutral microenvironments (Prosser, 1989), and the existence of acidophilic ammonia oxidizers. The last mechanism has been demonstrated by the cultivation of the first obligately acidophilic thaumarchaeon $N$. devanaterra (Lehtovirta-Morley et al., 2011). It can only grow in low $\mathrm{pH}$ liquid batches and $0.18 \mathrm{nM}$ ammonia, and is inhibited at neutral $\mathrm{pH}$ and high ammonia concentration. Future characterization of the mechanisms for acidophilic ammonia oxidation requires more deep studies on physiology and evolution of $N$. devanaterra.

\section{Concluding remarks and future perspectives}

Despite the fact that accumulated evidence and collected data strongly demonstrated the dominant role of thaumarchaea in ammonia oxidation of acidic soil ecosystems, it should also be taken into account that a wide range of physiological diversity of AOB could also contribute to nitrification in acidic environments. We still need more environmental investigations and microcosm incubations to differentiate the maximum contribution of AOB or other possible microorganisms to nitrification, and to explore the underlying mechanisms of AOA-driven nitrification in a wide range of acidic soils. What is more, we have to admit that factors and mechanisms driving the corresponding ammonia-oxidizing populations are still not fully understood. We do not know whether $\mathrm{pH}$ itself has directly shaped the ecological niches of AOA and AOB in acidic soils, or whether the differences are due to indirect influences induced by low pH. Actually, reduced availability of ammonia in acidic soils did not occur in isolation, as low-pH conditions could alter many other elements as well. Acidic soils are usually constrained for crop production by poor fertility, due to an integration of mineral toxicities and element deficiencies. The low-pH soil conditions could increase exposure to toxic metals such as aluminum, manganese, copper, iron, and zinc, simultaneously decreasing the bioavailability of elements like phosphorus, sulfur, and calcium (Goedert et al., 1997). Such acidity-induced effects would influence the growth of plants as well as soil-inhabiting microorganisms, certainly including thaumarchaeal and bacterial ammonia oxidizers. It was reported that some other elements in addition to nitrogen could also influence the community structure and abundance of ammonia oxidizers (Mertens et al., 2009; Liu et al., 2010). Erguder et al. (2009) reviewed the researchs on the effects of phosphate and sulfide on autotrophic ammonia oxidation, and suggested that AOA ecotypes might thrive in low phosphate availability and low sulfide-containing environments. Therefore, it is of great importance to investigate further whether direct acidity pressure or the availability of ammonia and some other necessary 
elements influenced by low $\mathrm{pH}$ values select the dominating ammonia oxidizers.

\section{Acknowledgments}

We appreciate the helpful comments and English improvements of Professor Jane Hughes from Griffith University, Australia. This work was financially supported by the National Science Foundation of China (41025004, 50921064 and 41020114001), the Chinese Academy of Sciences (KZCX2-YW-JC401), and the CAS/SAFEA International Partnership Program for Creative Research Teams of "Ecosystem Processes and Services".

\section{References}

Arp, D.J., Sayavedra-Soto, L.A., Hommes, N.G., 2002. Molecular biology and biochemistry of ammonia oxidation by Nitosomonas europaea. Archives of Microbiology 178, 250-255.

Beman, J.M., Popp, B.N., Francis, C.A., 2008. Molecular and biogeochemical evidence for ammonia oxidation by marine Crenarchaeota in the Gulf of California. The ISME Journal 2, 429-441.

Blainey, P.C., Mosier, A.C., Potanina, A., Francis, C.A., Quake, S.R., 2011. Genome of a low-salinity ammonia-oxidizing archaeon determined by single-cell and metagenomic analysis. Plos One 6, e16626.

Bollmann, A., Bar-Gilissen, M.J., Laanbroek, H.J., 2002. Growth at low ammonium concentrations and starvation response as potential factors involved in niche differentiation among ammonia-oxidizing bacteria. Applied and Environmental Microbiology 68, 4751-4757.

Bollmann, A., Schmidt, I., Saunders, A.M., Nicolaisen, M.H., 2005. Influence of starvation on potential ammonia-oxidizing activity and amoA mRNA levels of Nitrosospira briensis. Applied and Environmental Microbiology 71, 1276-1282.

Bomberg, M., Timonen, S., 2007. Distribution of cren- and euryarchaeota in scots pine mycorrhizospheres and boreal forest humus. Microbial Ecology 54, 406-416.

Booth, M.S., Stark, J.M., Rastetter, E., 2005. Controls on nitrogen cycling in terrestrial ecosystems: a synthetic analysis of literature data. Ecological Monographs 75, 139-157.

Bottomley, P.J., Taylor, A.E., Boyle, S.A., McMahon, S.K., Rich, J.J., Cromack, K. Myrold, D.D., 2004. Responses of nitrification and ammonia-oxidizing bacteria to reciprocal transfers of soil between adjacent coniferous forest and meadow vegetation in the Cascade Mountains of oregon. Microbial Ecology 48, 500-508.

Brochier-Armanet, C., Boussau, B., Gribaldo, S., Forterre, P., 2008. Mesophilic crenarchaeota: proposal for a third archaeal phylim, the Thaumarchaeota. Nature Reviews Microbiology 6, 245-252.

Burton, S.A.Q., Prosser, J.I., 2001. Autotrophic ammonia oxidation at low pH though urea hydrolysis. Applied and Environmental Microbiology 67, 2952-2957.

Carnol, M., Ineson, P., 1999. Environmental factors controlling leaching, $\mathrm{N}_{2} \mathrm{O}$ emissions and numbers of oxidizers in a coniferous forest soil. Soil Biology and Biochemistry 31, 979-990.

Carver, B.F., Ownby, J.D., 1995. Acid soil tolerance in wheat. Advances in Agronomy $54,117-173$.

Chen, X.P., Zhu, Y.G., Xia, Y., Shen, J.P., He, J.Z., 2008. Ammonia-oxidizing archaea: important players in paddy rhizosphere soil? Environmental Microbiology 10 1978-1987.

Chen, X., Zhang, L.M., Shen, J.P., Wei, W.X., He, J.Z., 2011. Abundance and community structure of ammonia-oxidizing archaea and bacteria in an acid paddy soil. Biology and Fertility of Soils 47, 323-331.

De Boer, W., Kowalchuk, G.A., 2001. Nitrification in acid soils: micro-organisms and mechanisms. Soil Biology and Biochemistry 33, 853-866.

De Boer, W., Laanbroek, H.J., 1989. Ureolytic nitrification at low pH by Nitrosospira Spec. Archives of Microbiology 152, 178-181.

De Boer, W., Duyts, H., Laanbroel, H.J., 1988. Autotrophic nitrification in a fertilized heath soil. Soil Biology and Biochemistry 20, 845-850.

De Boer, W., Gunnewiek, P., Troelstra, S., Laanbroek, H., 1989. Two types of chemolithotrophic nitrification in acid heathland humus. Plant and Soil 119, 229-235.

De Boer, W., Gunnewiek, P.J.A.K., Veenhuis, M., Bock, E., Laanbroek, H.J., 1991 Nitrification at low $\mathrm{pH}$ by aggregated chemolithotrophic bacteria. Applied and Environmental Microbiology 57, 3600-3604.

De Boer, W., Tietema, A., Klein Gunnewiek, P.J.A., Laanbroek, H.J., 1992. The autotrophic ammonia-oxidizing community in a nitrogen-saturated acid forest soil in relation to $\mathrm{pH}$-dependent nitrifying activity. Soil Biology and Biochemistry 24, 229-234.

de la Torre, J.R., Walker, C.B., Ingalls, A.E., Könneke, M., Stahl, D.A., 2008. Cultivation of a thermophilic ammonia oxidizing archaeon synthesizing crenarchaeol Environmental Microbiology 10, 810-818.

Degrange, V., Couteaux, M.M., Anderson, J.M., Berg, M.P., Lensi, R., 1998. Nitrification and occurrence of Nitrobacter by MPN-PCR in low and high nitrifying coniferous forest soils. Plant and Soil 198, 201-208.

Di, H.J., Cameron, K.C., Shen, J.P., Winefield, C.S., O'Callaghan, M., Bowatte, S., He, J.Z., 2009. Nitrification driven by bacteria and not archaea in nitrogen-rich grassland soils. Nature Geoscience 2, 621-624.
Di, H.J., Cameron, K.C., Shen, J.P., Winefield, C.S., O'Callaghan, M., Bowatte, S., He, J.Z., 2010. Ammonia-oxidizing bacteria and archaea grow under contrasting soil nitrogen conditions. FEMS Microbiology Ecology 72, 386-394.

Erguder, T.H., Boon, N., Wittebolle, L., Marzorati, M., Verstraete, W., 2009. Environmental factors shaping the ecological niches of ammonia-oxidizing archaea. FEMS Microbiology Reviews 33, 855-869.

Fan, F.L., Yang, Q.B., Li, Z.J., Wei, D., Cui, X.A., Liang, Y.C., 2011. Impacts of organic and inorganic fertilizers on nitrification in a cold climate soil are linked to the bacterial ammonia oxidizer community. Microbial Ecology 62, 982-990.

Frank, D.A., Groffman, P.M., Evans, R.D., Tracy, B.F., 2000. Ungulate stimulation of nitrogen cycling and retention in Yellowstone Park grasslands. Oecologia 123, 116-121.

Fred, E.B., Graul, E.J., 1916. Some factors that influence nitrate formation in acid soils. Soil Science 1, 317-323.

Frijlink, M.J., Abee, T., Laanbroek, H.J., Boer, W., Konings, W.N., 1992. Secondary transport of amino acids in Nitrosomonas europaea. Archives of Microbiology 157, 389-393.

Goedert, W., Lobato, E., Louren, O.S., 1997. Nutrient use efficiency in Brazilian acid soils: nutrient management and plant efficiency. In: Moniz, A.C., Furlani, A.M.C., Schaffert, R.E., Fageria, N.K., Rosolem, C.A., Cantarella, H. (Eds.), Plant-soil Interactions at Low PH. Brazilian Soil Science Society, pp. 97-104.

Groeneweg, J., Sellner, B., Tappe, W., 1994. Ammonia oxidation in Nitrosomonas at $\mathrm{NH}_{3}$ concentration near $\mathrm{K}_{\mathrm{m}}$ : effects of $\mathrm{pH}$ and temperature. Water Research 28 , 2561-2566.

Gubry-Rangin, C., Nicol, G.W., Prosser, J.I., 2010. Archaea rather than bacteria control nitrification in two agricultural acidic soils. FEMS Microbiology Ecology 74, 566-574.

Gubry-Rangin, C., Hai, B., Quince, C., Engel, M., Thomson, B.C., James, P., Schloter, M., 2011. Niche specialization of terrestrial archaeal ammonia oxidizers. Proceedings of the National Academy of Sciences of the United States of America 108, 21206-21211.

Hai, B., Diallo, N.H., Sall, S., Haesler, F., Schauss, K., Bonzi, M., Assigbetse, K. Chotte, J.L., Munch, J.C., Schloter, M., 2009. Quantification of key genes steering the microbial nitrogen cycle in the rhizosphere of sorghum cultivars in tropical agroecosystems. Applied and Environmental Microbiology 75, 4993-5000.

Hall, A.D., Miller, N.H.J., Gimingham, C.T., 1908. Nitrification in acid soils. Proceedings of the Royal Society B 80, 196-212.

Hallam, S.J., Mincer, T.J., Schleper, C., Preston, C.M., Roberts, K., Richardson, P.M., DeLong, E.F., 2006. Pathways of carbon assimilation and ammonia oxidation suggested by environmental genomic analyses of marine Crenarchaeota. Plos Biology 4, 520-536.

Hankinson, T.R., Schmidt, E.L., 1984. Examination of an acid forest soil for ammoniaoxidizing and nitrite-oxidizing autotrophic bacteria. Canadian Journal of Microbiology 30, 1125-1132.

Hart, S.C., Binkley, D., Perry, D.A., 1997. Influence of red alder on soil nitrogen transformations in two conifer forests of contrasting productivity. Soil Biology and Biochemistry 29, 1111-1123.

Hastings, R.C., Butler, C., Singleton, I., Saunders, J.R., MacCarthy, A.J., 2000. Analysis of ammonia-oxidizing bacteria populations in acid forest soil during conditions of moisture limitation. Letters in Applied Microbiology 30, 14-18.

Hatzenpichler, R., Lebedeva, E.V., Spieck, E., Stoecker, K., Richter, A., Daims, H., Wagner, M., 2008. A moderately thermophilic ammonia-oxidizing crenarchaeote from a hot spring. Proceedings of the National Academy of Sciences of the United States of America 105, 2134-2139.

He, J.Z., Shen, J.P., Zhang, L.M., Zhu, Y.G., Zheng, Y.M., Xu, M.G., Di, H.J., 2007. Quantitative analyses of the abundance and composition of ammonia-oxidizing bacteria and ammonia-oxidizing archaea of a Chinese upland red soil under long-term fertilization practices. Environmental Microbiology 9, 2364-2374.

Hommes, N.G., Sayavedra-Soto, L.A., Arp, D.J., 2003. Chemolithoorganotrophic growth of Nitrosomonas europaea on fructose. Journal of Bacteriology 185, 6809-6814.

Houzeau, A., 1872. Faits pour servir a l'histoire de la nitrification, composition des terreaux de tantah (basse-égypte). Annales De Chimie Et De Physique 25, 161-167.

Ingalls, A.E., Shah, S.R., Hansman, R.L., Aluwihare, L.I., Santos, G.M., Druffel, E.R.M., Pearson, A., 2006. Quantifying archaeal community autotrophy in the mesopelagic ocean using natural radiocarbon. Proceedings of the National Academy of Sciences of the United States of America 103, 6442-6447.

Islam, A., Chen, D., White, R.E., 2007. Heterotrophic and autotrophic nitrification in two acid pasture soils. Soil Biology and Biochemistry 39, 972-975.

Jiang, Q.Q., Bakken, L.R., 1999. Comparison of Nitrosospira strains isolated from terrestrial environments. FEMS Microbiology Ecology 30, 171-186.

Jia, Z.J., Conrad, R., 2009. Bacteria rather than Archaea dominate microbial ammonia oxidation in an agricultural soil. Environmental Microbiology 11, 1658-1671.

Jordan, F.L., Cantera, J.J.L., Fenn, M.E., Stein, L.Y., 2005. Autotrophic ammoniaoxidizing bacteria contribute minimally to nitrification in a nitrogenimpacted forested ecosystem. Applied and Environmental Microbiology 71, 197-206.

Jung, M.Y., Park, S.J., Min, D., Kim, J.S., Rijpstra, W.I.C., Damsté, J.S.S., Kim, G.J., Madsen, E.L., Rhee, S.K., 2011. Enrichment and characterization of an autotrophic ammonia-oxidizing archaeaon of mesophilic Crenarchaeal Group I.1a from an agricultural soil. Applied and Environmental Microbiology 77, 8635-8647.

Jurgens, G., Lindstrom, K., Saano, A., 1997. Novel group within the kingdom Crenarchaeota from boreal forest soil. Applied and Environmental Microbiology 63, 803-805.

Kemnitz, D., Kolb, S., Conrad, R., 2007. High abundance of Crenarchaeota in a temperate acidic forest soil. FEMS Microbiology Ecology 60, 442-448. 
Killham, K., 1990. Nitrification in coniferous forest soils. Plant and Soil 128, 31-44. Könneke, M., Bernhard, A.E., de la Torre, J.R., Walker, C.B., Waterbury, J.B., Stahl, D.A., 2005. Isolation of an autotrophic ammonia-oxidizing marine archaeon. Nature 437, 543-546.

Koops, H.P., Pommerening-Roser, A., 2001. Distribution and ecophysiology of the nitrifying bacteria emphasizing cultured species. FEMS Microbiology Ecology 37, 1-9.

Kreitinger, J.P., Klein, T.M., Novick, N.J., Alexander, M., 1985. Nitrification and characteristics of nitrifying microorganisms in an acid forest soil. Soil Science Society of America Journal 49, 1407-1410.

Laverman, A.M., Speksnijder, A.G.C.L., Braster, M., Kowalchuk, G.A., Verhoef, H.A., van Verseveld, H.W., 2001. Spatiotemporal stability of an ammonia-oxidizing community in a nitrogen-saturated forest soil. Microbial Ecology 42, 35-45.

Le Roux, X., Bardy, M., Loiseau, P., Louault, F., 2003. Stimulation of soil nitrification and denitrification by grazing in grasslands: do changes in plant species composition matter? Oecologia 137, 417-425.

Lehtovirta-Morley, L.E., Prosser, J.I., Nicol, G.W., 2009. Soil pH regulates the abundance and diversity of Group 1.1c Crenarchaeota. FEMS Microbiology Ecology 70, 367-376.

Lehtovirta-Morley, L.E., Stoecker, K., Vilcinskas, A., Prosser, J.I., Nicol, G.W., 2011. Cultivation of an obligate acidophilic ammonia oxidizer from a nitrifying acid soil. Proceedings of the National Academy of Sciences of the United States of America 108, 15892-15897.

Leininger, S., Urich, T., Schloter, M., Schwark, L., Qi, J., Nicol, G.W., Prosser, J.I., Schuster, S.C., Scleper, C., 2006. Archaea predominate among ammoniaoxidizing prokaryotes in soils. Nature 442, 806-809.

Levicnik-Höfferle, S., Nicol, G.W., Pal, L., Hacin, J., Prosser, J.I., Mandic-Mulec, I., 2010. Ammonium supply rate influences archaeal and bacterial ammonia oxidizers in a wetland soil vertical profile. FEMS Microbiology Ecology 74, 302-315.

Levicnik-Höfferle, S., Nicol, G.W., Ausec, L., Mulec, I., Prosser, J.I., 2012. Stimulation of thaumarchaeal ammonia oxidation by ammonia derived from organic nitrogen but not inorganic nitrogen. FEMS Microbiology Ecology 80, 114-123.

Liu, Y.R., Zheng, Y.M., Shen, J.P., Zhang, L.M., He, J.Z., 2010. Effects of mercury on the activity and community composition of soil ammonia oxidizers. Environmental Science and Pollution Research 17, 1237-1244.

Martens-Habbena, W., Berube, P.M., Urakawa, H., de la Torre, J.R., Stahl, D.A., 2009. Ammonia oxidation kinetics determine niche separation of nitrifying Archaea and Bacteria. Nature 461, 976-979.

Mertens, J., Broos, K., Wakelin, S.A., Kowalchuk, G.A., Springael, D., Smolders, E., 2009. Bacteria, not archaea, restore nitrification in a zinc-contaminated soil. The ISME Journal 3, 916-923.

Mintie, A.T., Heichen, R.S., Cromack, K., Myrold, D.D., Bottomley, P.J., 2003. Ammonia-oxidizing bacteria along meadow-to-forest transects in the oregon cascade mountains. Applied and Environmental Microbiology 69, 3129-3136.

Nicol, G.W., Tscherko, D., Embley, T.M., Prosser, J.I., 2005. Primary succession of soil Crenarchaeota across a receding glacier foreland. Environmental Microbiology 7, 337-347.

Nicol, G.W., Leininger, S., Schleper, C., Prosser, J.I., 2008. The influence of soil pH on the diversity, abundance and transcriptional activity of ammonia oxidizing archaea and bacteria. Environmental Microbiology 10, 2966-2978.

Noyes, H.A., Conner, S.D., 1919. Nitrates, nitrification, and bacterial contents of five typical acid soils as affected by lime, fertilizer, crops, and moisture. Journal of Agricultural Research 16, 27-42.

Ochsenreiter, T., Selezi, D., Quaiser, A., Bonch-Osmolovskaya, L., Schleper, C., 2003. Diversity and abundance of Crenarchaeota in terrestrial habitats studied by $16 \mathrm{~S}$ RNA surveys and real time PCR. Environmental Microbiology 5, 787-797.

Offre, P., Prosser, J.I., Nicol, G.W., 2009. Growth of ammonia-oxidizing archaea in soil microcosms is inhibited by acetylene. FEMS Microbiology Ecology 70, 99-108.

Papen, H., Von Berg, R., 1998. A most probable number (MPN) for estimation of cell numbers of heterotrophic nitrifying bacteria in soil. Plant and Soil 199, 123-130.

Park, B.J., Park, S.J., Yoon, D.N., Schouten, S., Damsté, J.S.S., Rhee, S.K., 2010. Cultivation of autotrophic ammonia-oxidizing archaea from marine sediments in coculture with sulfur-oxidizing bacteria. Applied and Environmental Microbiology 76, 7575-7587.

Pedersen, H., Dunkin, K.A., Firestone, M.K., 1999. The relative importance of autotrophic and heterotrophic nitrification in a conifer forest soil as measured by $\mathrm{N}^{15}$ tracer and pool dilution techniques. Biogeochemistry 44, 135-150.

Pennington, P.I., Ellis, R.C., 1993. Autotrophic and heterotrophic nitrification in acidic forest and native grassland soils. Soil Biology and Biochemistry 25, 1399-1408.

Pester, M., Schleper, C., Wagner, M., 2011. The Thaumarchaeota: an emerging view of their phylogeny and ecophysiology. Current Opinion in Microbiology 14, 300-306

Prosser, J.I., 1989. Autotrophic nitrification in bacteria. Advances in Microbial Physiology 30, 125-181.

Rosso, L., Lobry, J.R., Bajard, S., Flandrois, J.P., 1995. Convenient model to describe the combined effects of temperature and $\mathrm{pH}$ on microbial growth. Applied and Environmental Microbiology 61, 610-616.

Rousk, J., Bååth, E., Brookes, P.C., Lauber, C.L., Lozupone, C., Caporaso, J.G., Knight, R., Fierer, N., 2010. Soil bacterial and fungal communities across a $\mathrm{pH}$ gradient in an arable soil. The ISME Journal 4, 1340-1351.

Santoro, A.E., Francis, C.A., de Sieyes, N.R., Boehm, A.B., 2008. Shifts in the relative abundance of ammonia-oxidizing bacteria and archaea across physicochemical gradients in a subterranean estuary. Environmental Microbiology 10, 1068-1079.
Sato, C., Schnoor, J.L., Mcdonald, D.B., Huey, J., 1985. Test medium for the growth of nitrosomonas-europaea. Applied and Environmental Microbiology 49, 1101-1107.

Schauss, K., Focks, A., Leininger, S., Kotzerke, A., Heuer, H., Thiele-Bruhn, S. Sharama, S., Wilke, B.M., Matthies, M., Smalla, K., Munch, J.C., Amelung, W. Kaupenjohann, M., Schloter, M., Schleper, C., 2009. Dynamics and functional relevance of ammonia-oxidizing archaea in two agricultural soils. Environmental Microbiology 11, 446-456.

Schleper, C., Jurgens, G., Jonuscheit, M., 2005. Genomic studies of uncultivated archaea. Nature Reviews Microbiology 3, 479-488.

Schleper, C., 2010. Ammonia oxidation: different niches for bacteria and archaea? The ISME Journal 4, 1092-1094.

Schmidt, C.S., Hultman, K.A., Robinson, D., Killham, K., Prosser, J.I., 2007. PCR profiling of ammonia-oxidizer communities in acidic soils subjected to nitrogen and sulphur deposition. FEMS Microbiology Ecology 61, 305-316.

Smits, N.A.C., Hefting, M.M., Kamst-van Agterveld, M.P., Laanbroek, H.J. Paalman, A.J., Robbink, R., 2010. Nitrification along a grassland gradient: inhibition found in matgrass swards. Soil Biology and Biochemistry 42, 635-641.

Stehr, G., Bottcher, B., Dittberner, P., Rath, G., Koops, H.P., 1995. The ammoniaoxidizing nitrifying population of the river Elbe estuary. FEMS Microbiology Ecology 17, 177-186.

Stephen, J.R., McCaig, A.E., Smith, Z., Prosser, J.I., Embley, T.M., 1996. Molecular diversity of soil and marine 16S rRNA gene sequences related to beta-subgroup ammoniaoxidizing bacteria. Applied and Environmental Microbiology 62, 4147-4154.

Stopnišek, N., Gubry-Rangin, C., Levicnik-Höfferle, S., Nicol, G.W., Mandic-Mulec, I., Prosser, J.I., 2010. Thaumarchaeal ammonia oxidation in an acidic forest peat soil is not influenced by ammonium amendment. Applied and Environmental Microbiology 76, 7626-7634.

Strong, D.T., Sale, P.W.G., Helyar, K.R., 1997. Initial soil pH affects the pH at which nitrification ceases due to self-induced acidification of microbial microsites. Australian Journal of Soil Research 35, 565-570.

Suwa, Y., Imamura, Y., Suzuki, T., Tashiro, T., Urushigawa, Y., 1994. Ammoniaoxidizing bacteria with different sensitivities to $\left(\mathrm{NH}_{4}\right)_{2} \mathrm{SO}_{4}$ in activated sludges. Water Research 28, 1523-1532.

Suzuki, I., Dular, U., Kwok, S.C., 1974. Ammonia or ammonium ion as substrate for oxidation by nitrosomonas-europaea cells and extracts. Journal of Bacteriology 120, 556-558.

Tourna, M., Stieglmeier, M., Spang, A., Könneke, M., Schintlmeister, A., Urich, T. Engel, M., Schloter, M., Wagner, M., Richter, A., Schleper, C., 2011. Nitrososphaera viennensis, an ammonia oxidizing archaeon from soil. Proceedings of the National Academy of Sciences of the United States of America 108, $8420-8425$.

Treusch, A.H., Leininger, S., Kietzin, A., Schuster, S.C., Klenk, H.P., Schleper, C., 2005 Novel genes for nitrite reductase and amo-related proteins indicate a role of uncultivated mesophilic crenarchaeota in nitrogen cycling. Environmental Microbiology 7, 1985-1995.

Valentine, D.L., 2007. Adaptations to energy stress dictate the ecology and evolution of the archaea. Nature Reviews Microbiology 5, 316-323.

Venter, J.C., Remington, K., Heidelberg, J.F., Halpern, A.L., Rusch, D., Eisen, J.A., 2004 Environmental genome shotgun sequencing of the Sargasso Sea. Science 304 66-74.

Verhamme, D.T., Prosser, J.I., Nicol, G.W., 2011. Ammonia concentration determines differential growth of ammonia-oxidising archaea and bacteria in soil microcosms. The ISME Journal 5, 1067-1071.

Vitousek, P.M., Aber, J.D., Howarth, R.W., Likens, G.E., Matson, P.A., Schindler, D.W. Schlesinger, W.H., Tilman, D.G., 1997. Human alteration of the global nitrogen cycle: sources and consequences. Ecological Applications 7, 737-750.

Vonuexkull, H.R., Mutert, E., 1995. Global extent, development and economic impact of acid soils. Plant and Soil 171, 1-15.

Walker, C.B., de la Torre, J.R., Klotz, M.G., Urakawa, H., Pinel, N., Arp, D.J., 2010 Nitrosopumilus maritimus genome reveals unique mechanisms for nitrification and autotrophy in globally distributed marine crenarchaea. Proceedings of the National Academy of Sciences of the United States of America 107, 8818-8823.

Winogradsky, S., 1890. Recherches sur les organismes de la nitrification, vol. 4. Ann Inst Pasteur, pp. 11-12.

Wrage, N., Velthof, G.L., van Beusichem, M.L., Oenema, O., 2001. Role of nitrifier denitrification in the production of nitrous oxide. Soil Biology and Biochemistry 33, 1723-1732.

Xia, W.W., Zhang, C.X., Zeng, X.W., Feng, Y.Z., Weng, J.H., Lin, X.G., Zhu, J.G., Xiong, Z.Q., Xu, J., Cai, Z.C., Jia, Z.J., 2011. Autotrophic growth of nitrifying community in an agricultural soil. The ISME Journal 5, 1226-1236.

Yao, H.Y., Gao, Y.M., Nicol, G.W., Campbell, C.D., Prosser, J.I., Zhang, L.M., Han, W.Y., Singh, B.K., 2011. Links between ammonia oxidizer community structure, abundance, and nitrification potential in acidic soils. Applied and Environmental Microbiology 77, 4618-4625.

Ying, J.Y., Zhang, L.M., He, J.Z., 2010. Putative ammonia-oxidizing bacteria and archaea in an acidic red soil with different land utilization patterns. Environmental Microbiology Reports 2, 304-312.

Zhang, L.M., Offre, P.R., He, J.Z., Verhamme, D.T., Nicol, G.W., Prosser, J.I., 2010. Autotrophic ammonia oxidation by soil thaumarchaea. Proceedings of the National Academy of Sciences of the United States of America 107, 17240-17245.

Zhang, L.M., Hu, H.W., Shen, J.P., He, J.Z., 2012. Ammonia-oxidizing archaea have more important role than ammonia-oxidizing bacteria in ammonia oxidation of strongly acidic soils. The ISME Journal 6, 1032-1045. 